\title{
Measles in Nigerian children
}

A study of the disease in West Africa, and its manifestations in England and other countries during different epochs

\author{
By D. MORLEY, M.D., D.C.H.,* \\ MARGARET WOODLAND, S.R.N., S.C.M.,
}

Child Health Unit of the West African Council for Medical Research,

Wesley Guild Hospital, Ilesha, Nigeria

AND

W. J. MARTIN, Ph.D., D.Sc.,

Medical Research Council, Statistical Research Unit, London School of Hygiene and Tropical Medicine

\section{(Received 7 September 1962)}

'The measles which are of a deep red and violet colour are of a bad and fatal kind.'

Rhazes, A.D. 850

During the years 1956-61 an investigation into morbidity and mortality among children under 5 was undertaken in the village of Imesi, Western Nigeria, and at the nearby Wesley Guild Hospital in Ilesha. One of its results was to emphasize the contribution to morbidity and mortality made by the infective diseases of childhood. Of the acute infective fevers, measles, with its complications, was found to be outstanding as a cause of death.

In this paper an attempt will be made to describe some of the epidemiological and clinical characteristics of measles in West Africa today; they are quite unlike present experience of the disease in England. It will be shown that the disease in West Africa seems to resemble closely measles as seen in England prior to the 20th century. In the description of measles in West Africa, special attention will be given to its effect on the child's nutrition, and it will be shown that it is often responsible for the development of kwashiorkor.

\section{BACKGROUND TO THE STUDY}

Ilesha lies $\mathbf{7 4}$ miles north-east of Ibadan, in the rain forest area of Southern Nigeria. The Wesley Guild Hospital serves a population of 75,000 in the township, and draws many patients from the surrounding villages, where a further 75,000 live. Yorubas predominate, the majority being farmers producing yams, maize and cassava, with cocoa as the cash crop.

Within recent years the hospital has rapidly expanded, and there has been an explosive increase in the number of child out-patients. Simultaneously, the

* Now in the Department of Human Nutrition in the London School of Hygiene and Tropical Medicine. 
paediatric services have been improved, and research in the paediatric field undertaken. But in spite of these developments, the hospital has difficulty in meeting the needs of the people.

No attempt has been made, in organizing the hospital services, to separate curative and preventive paediatrics. All children under 5 attend one clinic, at which there is a daily attendance of about 400 children on 6 days a week. The children are all seen and treated by locally trained nurses who have been given additional training in malaria, malnutrition, whooping cough, smallpox and tuberculosis, and in how to treat, in their early stages, the acute respiratory and diarrhoeal illnesses which are so common among Nigerian children. Only children with complex conditions and those who are seriously ill are referred to the paediatrician.

\section{LONGITUDINAL STUDY IN IMESI}

Imesi is a village 95 miles from Ibadan, in Western Nigeria. Situated nearly $1000 \mathrm{ft}$. above sea level, it lies on a small plateau in the hills, 25 miles north-east of Ilesha. In November 1956 it was chosen as the site for a longitudinal study of children, which began during their mothers' pregnancy. The investigation, centred in a dispensary, was undertaken by a paediatrician (D. M.) and a nursing sister (M. W.); the latter has been permanently resident in the village throughout, except for periods of furlough, when a relief nursing sister took over. In addition to carrying out the research, these workers also offered medical services to those of the population of 5000 who desired them. The study was designed to trace the growth and development of a group of 405 African village children from birth to 5 years. In this paper, records of the first three years are used.

\section{THE INCIDENCE AND SEVERITY OF MEASLES}

Measles occurs every year in this part of Nigeria, but the outbreak is more severe in alternate years. The epidemic begins in the middle of the dry season, and declines with the onset of the wet season (Morley, 1962). During the dry season there is little activity on the farms and the people celebrate various festivals. At these festivals, which are spent in dancing and feasting, the child is carried on the mother's back, and excellent opportunities are presented for the spread of droplet infections. The decline of the epidemic is associated with the coming of the rains, when the people spend much of their time on the farms, planting the next season's crops. The rise and fall of the measles epidemic may be associated with these movements of population.

Of the 405 children in the Imesi village study, 82 were stillborn or died from causes unrelated to measles, so that full records of only 323 children are available; of them, 222 had measles during the study period, and among these children with measles there were 15 deaths in which the disease played a major part. Clinical data relating to 12 of these fatal cases are available, and are used in the descriptions of bronchopneumonia, diarrhoea and kwashiorkor given in a later section.

Similarly in the hospital at Ilesha measles was a frequent and severe disease among the child patients. During 1961, 2030 cases of measles were seen in the children's clinics. In the 3-year period ending June 1961, 1283 children with 
measles were admitted to the children's ward; of these 1283 children, 325 died, a mortality of $25 \cdot 3 \%$.

Gans, Macnamara, Morley, Thomson \& Watt (1961) have estimated an overall case mortality of $5 \%$ in Nigeria. The following figures, though limited, suggest a high mortality throughout West Africa.

Vallée de Sénégal. In 1956-7, Cantrelle, Etifier \& Masse, (1960) reported from this area that measles accounted for $24 \%$ of all deaths in children under the age of 15 , and diarrhoea complicating measles, a further $13 \%$. Senecal, Aubry \& Falade (1962) considered measles to be the most killing disease of the pre-school child.

Gambia. In an outbreak in the village of Keneba, the first for 12 years, $18 \%$ of the children under 5 died (McGregor, 1962).

Sierra Leone. Avery (1962) analysed 573 admissions for measles to the Nixon Memorial Hospital, Segbwema, between 1954-61, and reported a $17 \%$ mortality.

Haute Volta. In 1960 measles accounted for $50 \%$ of all deaths in the age group 1-4 years (Boué, 1962).

Ghana. Murphy (1962) reported a $15 \%$ mortality among 157 children admitted with measles to an Accra hospital. Of 330 children admitted with kwashiorkor, 62 had measles in the preceding 6 months. Field studies in Ghana suggest a mortality in excess of $3 \%$.

Lagos, Nigeria. Gans (1961) recorded that during 1959, 185 children with measles were admitted to the Lagos General Hospital; of these, 42 died, a mortality of $22.7 \%$.

Congo. McFie \& Yarom (1962) recorded 7 deaths in a group of 36 children who developed measles.

Statements to the effect that measles, as an endemic disease, is less prevalent in the tropics than in the temperate zone, and less serious among negro than white populations, are still to be found in some text-books. Some contribution to this belief may have been made by the fact that African parents have tended to regard an attack of measles as a 'normal' and inevitable occurrence in the life of their children and hence did not consider it worthwhile to bring them to hospital when they were suffering from it. This in turn meant that doctors in Africa gained little experience of the disease and hence erroneous ideas about its prevalence. In this connexion, a distinction must of course be made between endemic measles and the severe epidemics which have sometimes followed the introduction of the disease into isolated communities, an account of which will be found in a review by Brincker (1938). These are unlikely to recur, since modern developments in transport have eliminated isolation and no community can now remain free from measles for a long period and hence become susceptible to epidemics.

\section{MORTALITY FROM MEASLES IN THE PAST}

Creighton (1894) gives many accounts of epidemics with a high mortality, the highest of which seems to have been recorded by Gannelon (1892) in the Hospice des Enfants Assistés in Paris. In this orphanage, between the years 1867-72, there were 612 deaths among 1256 children who developed measles. Glasgow provides 
an example of high mortality in the general population; in the years 1807-12, measles accounted for $10.76 \%$ of all deaths in that city. Over the next 100 years the mortality declined, but still remained high among young children, as is shown in Table 1.

Table 1. Comparative mortality from measles in Great Britain and West Africa

\begin{tabular}{|c|c|c|c|c|}
\hline \multirow[b]{2}{*}{$\begin{array}{c}\text { Age } \\
\text { (years) }\end{array}$} & \multicolumn{2}{|c|}{ Glasgow, 1908} & \multicolumn{2}{|c|}{ England and Wales, 1960} \\
\hline & $\begin{array}{l}\text { Notifications } \\
\text { per } 100,000 \\
\text { population }\end{array}$ & \% mortality & $\begin{array}{l}\text { Notifications } \\
\text { per } 100,000 \\
\text { population }\end{array}$ & $\%$ mortality \\
\hline Under 1 & 7337 & $11 \cdot 7$ & 777 & $0 \cdot 104$ \\
\hline $1-$ & 14177 & $14 \cdot 2$ & 2126 & 0.045 \\
\hline 2- & 17422 & $4 \cdot 2$ & 2740 & $0 \cdot 046$ \\
\hline 3- & 16643 & $1 \cdot 7$ & 3041 & 0.010 \\
\hline 4-5 & 16560 & $1 \cdot 2$ & 3242 & $0 \cdot 005$ \\
\hline Under 5 & 14215 & $5 \cdot 8$ & 2356 & 0.030 \\
\hline & \multicolumn{2}{|c|}{$\begin{array}{l}\text { London fever hospitals, } \\
\qquad 1911-14\end{array}$} & \multicolumn{2}{|c|}{$\begin{array}{l}\text { Ilesha, W. Nigeria, } \\
\text { July 1958-61 }\end{array}$} \\
\hline $\begin{array}{c}\text { Age } \\
(\text { years })\end{array}$ & $\begin{array}{l}\text { Hospital } \\
\text { admissions }\end{array}$ & $\begin{array}{c}\text { Case fatality } \\
(\%)\end{array}$ & $\begin{array}{l}\text { Hospital } \\
\text { admissions }\end{array}$ & $\begin{array}{c}\text { Case fatality } \\
(\%)\end{array}$ \\
\hline Under 1 & 1080 & 22.9 & 276 & $19 \cdot 9$ \\
\hline $1-$ & 2728 & $21 \cdot 3$ & 521 & 29.9 \\
\hline 2- & 2125 & $11 \cdot 8$ & 217 & $26 \cdot 7$ \\
\hline $3-$ & 1874 & $7 \cdot 1$ & 138 & $21 \cdot 7$ \\
\hline 4-5 & 1470 & $5 \cdot 2$ & 72 & $23 \cdot 6$ \\
\hline Under 5 & 9277 & 13.9 & 1224 & $25 \cdot 8$ \\
\hline
\end{tabular}

Table 1 gives comparative data on mortality from measles in infants and young children in Glasgow in 1908 and England and Wales in 1960, the former taken from the Annual Report of the Registrar-General for Scotland, 1908, and Chalmers' The Health of Glasgow, 1818-1925, the latter from the Annual Report of the RegistrarGeneral for England and Wales, 1960. Case fatality in London fever hospitals 1911-14, as derived from the Reports of the Local Government Board, (1918) is compared with that in the Ilesha hospital, 1958-61. The latter comparison raises a point of interest, namely that the fatality in the Ilesha children in the age group 3-5 years was higher than that in London children 50 years ago, perhaps because only serious cases were admitted to the Ilesha hospital, and because malnutrition contributes to measles mortality in African children.

\section{THE CLINICAL PICTURE OF MEASLES IN WEST AFRICA}

Certain aspects of the clinical picture in West African children are of special importance. Bronchopneumonia, laryngitis and diarrhoea are common and serious accompaniments of the disease; darkening of the rash followed by extensive desquamation is frequently seen; the effect of the disease on the state of nutrition is severe.

The clinical accounts which follow are confined largely to bronchopneumonia, 
diarrhoea, malnutrition and skin changes. Encephalitis, cancrum oris, conjunctivitis, and keratitis leading to blindness, which are not uncommon accompaniments of the disease in West Africa, will not be considered in the paper.

The term 'complication' is avoided, because it is impossible to distinguish between clinical signs which are part of the disease and signs superimposed on it.

\section{Measles bronchopneumonia}

In the village study, as far as possible, day to day examinations of children with measles were made. Dyspnoea and crepitations audible on auscultation of the chest were often observed in the early stages before secondary bacterial infection was likely to have occurred. There were a number of instances of clear-cut bronchopneumonia, of which the following are examples:

No. 288, N.D. (F) aged 13 months, developed measles on 9 March 1959. As the rash appeared, she had some diarrhoea and vomiting, and was treated with sulphadimidine. Ten days later she was brought back to the dispensary, looking very miserable, with a running nose, desquamation of the skin, and dyspnoea. Crepitations were present at both lung bases. She was treated with penicillin, to which was added streptomycin the following day. With this treatment, she made a good recovery during the next 6 days. In this child the skin changes and the bronchopneumonia developed simultaneously; this association was seen many times, and will be referred to again later.

Among the village children there were four deaths associated with measles bronchopneumonia. All four children showed some degree of marasmus. Recent whooping cough, anaemia and convulsions respectively, were present in three. The fourth is perhaps typical of this type of case, and is described below:

No. 61, M.J. (F) aged 12 months. M.J. had gained weight fairly satisfactorily until the 4th month, but from then until the 9th month she had not gained weight well. From the 9 th months until her death, her mother received a skimmed milk supplement to give to her. She was seen on 3, 4 and 5 January 1958, with fever, misery and cough; she was 1 year old, and weighed only $13 \mathrm{lb}$. The rash of measles did not become obvious until 11 January. During the next 3 days the child became very ill and was treated at first with sulphadimidine and penicillin, and later with chloramphenicol. On the 5th day following the appearance of the rash, the skin started to desquamate in large plaques. Cough and misery became worse, and the child steadily lost weight, losing 1 lb. in 9 days. She died 9 days after the appearance of the rash.

In the hospital at Ilesha, severe bronchopneumonia exceeded other manifestations of measles as a reason for admission (Table 2). The children in Ilesha were not under such close observation as those in the village of Imesi, and their condition was usually serious on admission.

Of the 1283 children admitted with measles to the Ilesha hospital, 604 had bronchopneumonia as the most prominent condition : of these $169(28 \%)$ died. The children aged 6-12 months showed a lower mortality (23\%) than those in the 2nd year of life; 276 in this age group were admitted, with a mortality of $32 \%$. This difference may well have been due to selective admission, but it was our impression 
that measles was more severe in the 2nd year than in the latter half of the 1st year, when breast milk was more abundant, and the state of nutrition of the children more satisfactory. Furthermore, in a proportion of the younger children the disease may have been mitigated by traces of maternal antibody.

Table 2. Measles bronchopneumonia, admissions to Ilesha Hospital, W. Nigeria, July 1958-June 1961

$\begin{array}{lccccccccc} & \begin{array}{c}-6 \\ \text { months }\end{array} & \begin{array}{c}6 \\ \text { months- }\end{array} & \begin{array}{c}1 \\ \text { year- }\end{array} & \begin{array}{c}2 \\ \text { years- }\end{array} & \begin{array}{c}3 \\ \text { years- }\end{array} & \begin{array}{c}4 \\ \text { years- }\end{array} & \begin{array}{c}5 \\ \text { years- }\end{array} & \begin{array}{c}6 \\ \text { years- }\end{array} & \begin{array}{c}9-12 \\ \text { years }\end{array} \\ \text { Affected } & 5 & 139 & 276 & 80 & 54 & 23 & 10 & 15 & 2 \\ \text { Died } & 0 & 32 & 89 & 27 & 10 & 7 & 1 & 3 & 0\end{array}$

Three centuries ago, Thomas Sydenham (1674) had little doubt as to the severity of measles bronchopneumonia. In describing its symptoms he says they ' $\ldots$ are so fatal, that they do more to fill Charon's boat than the smallpox itself'. Gregory (1843) records that in 1839 , a peak year, measles was responsible for 10,937 deaths in England and Wales, a third of all deaths due to epidemic diseases in that year. In the same book he suggests that as many as nine-tenths of the deaths from measles may have been due to pneumonia. Trousseau (1869) observed an epidemic at the Necker hospital in Paris in 1845, in which 22 out of 24 children with measles died from pneumonia. In England today, however, bronchopneumonia is no longer a frequent cause of death following measles. Watson (1956) reported from the results of a study of 993 cases of measles as seen in general practice, that chest conditions of any kind occurred in only 30 previously healthy children, while ear conditions occurred in 51. It appears that mortality from measles bronchopneumonia in England was declining before the 'thirties' of this century, that is, before the introduction of sulphonamide and antibiotics. Experience in Nigeria shows that they are valuable in the treatment of measles bronchopneumonia and will prevent some deaths from this cause. But they can have been only partly responsible for the decline in the incidence of measles bronchopneumonia, and the mortality associated with it, in England during recent decades.

\section{Laryngitis}

Among the Imesi village children, laryngitis associated with measles developed a number of times. None of these children required admission to hospital. Among the 1283 children admitted to Ilesha Hospital with measles, laryngitis, severe enough to cause concern, was present in $32(2 \cdot 3 \%)$. Among these 32 , there were 8 deaths, $2.5 \%$ of all the measles deaths. Laryngitis was particularly common and serious between the 1st and 3rd birthdays; 21 of the children admitted for laryngitis, and all the fatal cases, belonged to this age group.

Balme (1904) found laryngitis to be present in $8 \%$ of 227 children with measles seen at a clinic for the London poor in 1904. Holt (1911) stated, in the sixth edition of his Diseases of Children, that severe catarrhal laryngitis occurred in about $10 \%$ of children with measles, and might give rise to signs closely resembling those of membranous laryngitis. According to a Report of the Local Government Boards 
(1918), there were 248 deaths due to laryngitis associated with measles in 1911, $1.9 \%$ of all deaths from measles in that year. Thursfield (1914) recorded that tracheotomy was usually fatal in this condition. At Ilesha, this operation was performed on six children, of whom four died.

\section{Diarrhoea associated with measles}

Both among the village children and among those admitted to the children's ward at Ilesha, diarrhoea came second in importance only to bronchopneumonia as a feature of measles. The Ilesha people themselves know that diarrhoea is a dangerous occurrence, and fear it; sometimes the parents of children with measles specifically ask how it can be prevented. Diarrhoea occurs in many of the acute diseases of childhood, and its frequency in relation to these was investigated in the village study. In a group of 259 children who were permanently in the village, and observed for 3 years, 1804 attacks of diarrhoea were recorded, of which 179 were associated with acute infections. The frequency of the occurrence of diarrhoea in different infections is shown in Table 3.

Table 3. Acute infections that were associated with diarrhoea in Imesi village children

Condition No. of attacks

$\begin{array}{lr}\text { Measles } & 109 \\ \text { Whooping cough } & 26 \\ \text { Malaria } & 10 \\ \text { Ear infections } & 8 \\ \text { Respiratory } & 7 \\ \text { Other } & 19 \\ & 179\end{array}$

Table 4. Time relationship between 205 attacks of diarrhoea and appearance of rash in 142 children

$\begin{array}{ccccc}\begin{array}{c}7-14 \text { days } \\ \text { before rash }\end{array} & \begin{array}{c}1-6 \text { days } \\ \text { before rash }\end{array} & \begin{array}{c}0-6 \text { days } \\ \text { after rash }\end{array} & \begin{array}{c}7-14 \text { days } \\ \text { after rash }\end{array} & \begin{array}{c}\text { Later } \\ 11\end{array} \\ 39 & 50 & 23 & 82\end{array}$

Table 3 shows that in this community, diarrhoea is more commonly associated with measles than with the other diseases listed. The time relationship between attacks of diarrhoea and the appearance of the rash is shown in Table 4.

Diarrhoea may occur in the prodromal period or together with the rash. The children observed in Imesi were susceptible to diarrhoea for a long period after the measles itself had subsided, as is shown in Table 4. The diarrhoea may continue or reappear over a period of many weeks.

In five children diarrhoea following measles was a major factor in the child's death. The following history is typical of these children:

No. 150, A.S. (M) aged 35 months. The child had been brought regularly to the clinic by his mother. Weight gains had been satisfactory, the weight keeping 1-4 lb. above the mean weight for children in this area. When the child was seen on 
2 August 1960, the mother gave a history of measles beginning a few days previously. This was confirmed by the condition of the child's skin, which showed peeling. He was severely anaemic, and ova of Ancylostoma duodenale were found in his stool. On 6 August he had a discharging ear, and on the 9th he had signs of bronchopneumonia, for which he was treated. On 13 August he was brought with a most profuse diarrhoea. As the child was being examined on his mother's knee, there was a continual dripping of blood-stained stools into a bowl below. His weight had fallen from $29 \mathrm{lb} .4 \mathrm{oz}$. to $22 \mathrm{lb} .8 \mathrm{oz}$. during the month since he had contracted measles, a loss of $24 \%$. He was admitted to hospital for treatment with parenteral fluid, but died in a convulsion the following day. Death was considered to be due to measles associated with diarrhoea, bronchopneumonia, and anaemia.

Of the 1283 children admitted to Ilesha hospital for measles, $355(28 \%)$ had diarrhoea and dehydration as one of the major signs. The age of these children, and the number of deaths, is shown in Table 5 .

Table 5. The age distribution and mortality in 355 children with measles accompanied by diarrhoea

$\begin{array}{lcccccccc} & -1 & 1 & 2 & 3 & 4 & 5 & 6 & 9 \\ & \text { year } & \text { year- } & \text { years- } & \text { years- } & \text { years- } & \text { years- } & \text { years- } & \text { years + } \\ \text { Affected } & 78 & 131 & 66 & 43 & 21 & 7 & 9 & - \\ \text { Died } & 12 & 42 & 24 & 13 & 7 & 2 & 3 & -\end{array}$

From Table 5 it will be seen that children of all ages are prone to diarrhoea, and the mortality from this cause is high in all age groups. Of the children admitted with diarrhoea, $196(55 \%)$ required parenteral fluid therapy.

McGregor (1962) observed that after a severe outbreak of measles in the village of Keneba, in the Gambia, many of the children had diarrhoea, and that the stools were commonly blood-stained. At Imesi, diffuse diarrhoea was sometimes seen in association with measles, but the most common sign was the passing of mucus in the stool, with tenesmus. Blood was noticed in the stools of $13 \%$ of these children.

An early account of measles in West Africa was given by Daniell in 1852. He believed that dysentery and diarrhoea were then more serious and fatal than pneumonia among the African children. Diarrhoea occurring in the course of measles is now seldom mentioned in text-book descriptions of the disease, and is rarely seen in England or the U.S.A. Early in the 20th century it was still important; in Balme's account (1904) of an epidemic seen at a clinic for the London poor in 1904, it is recorded that out of 227 cases, $64(28 \%)$ had diarrhoea. D. Williams, (1906), states that 'Diarrhoea of foul-smelling slimy stools very commonly occurs during the eruptive stages, either at the onset of the rash or as it fades'. He later adds: 'Diarrhoea of a dysenteric character, due apparently to diffuse catarrhal colitis, sometimes occurs, and is very apt to continue as a chronic condition for weeks or months'. In certain earlier epidemics, diarrhoea seems to have been particularly severe. Creighton (1894), writing of the epidemics in 1807 and 1808 in Glasgow and Edinburgh, records that ' ...there 
were troublesome symptoms in almost every case - a violent pain in the belly, frequently accompanied with diarrhoea (and even with vomiting), and with the dysenteric symptoms of tenesmus and mucus in the stools. This bowel complaint usually lasted three or four days and wasted the patients remarkably.' This picture of diarrhoea closely resembles that seen in the African children, among whom the passage of mucus and tenesmus were particularly common. Many of the African children showed severe wasting associated with the diarrhoea, an observation which will be considered later under 'Weight loss'. In the village, the diarrhoea most commonly appeared after the rash, during or after the period of desquamation (Table 4). Thursfield (1914), in England, recorded that fatal diarrhoea usually occurred in the convalescent stages, and that in the eruptive stage it was usually harmless.

\section{Loss of weight, wasting and kwashiorkor}

The considerable loss of weight which follows measles was an important observation in the longitudinal child study in Imesi village. It was found that measles, whooping cough, cessation of breast feeding, and the birth of a sibling, were the most common events associated with a striking loss of weight. The weight changes occurring after measles in 220 children in Imesi were analysed and expressed as a percentage of the child's weight immediately prior to the measles infection. The results are shown in Table 6.

Table 6. Percentage of former weight lost during measles by 220 Imesi village children

$\begin{array}{lccllcc} & \text { None } & \text { Under 5\% } & 5 \%- & 10 \%- & 15 \%- & \begin{array}{c}20 \% \\ \text { and over }\end{array} \\ \text { No. of children } & 24 & 71 & 72 & 34 & 16 & 3 \\ \text { Percentage } & 11 & 32 & 32 \cdot 7 & 15.5 & 7.3 & 1.5\end{array}$

Table 7. Time taken to regain former weight after measles, Imesi village children

$\begin{array}{lcccc} & 0-4 \text { weeks } & 5-8 \text { weeks } & 9-12 \text { weeks } & \text { Over } 12 \text { weeks } \\ \text { No. of children } & 77 & 70 & 16 & 29 \\ & (40 \%) & (36.5 \%) & (8 \cdot 3 \%) & (15 \cdot 1 \%)\end{array}$

Mean period $=7 \cdot 2 \pm 0 \cdot 45$ weeks

Table 6 shows that almost one in four of the children lost more than $10 \%$ of their former weight as a result of this infection. In Table 7 the duration of weight loss is recorded for 192 children who attended regularly and who were weighed for a period after the disease.

The height of the children included in the study was measured every 6 months. The height records of 38 children who had taken 8 weeks or more to recover their weight after measles were analysed. No significant change in the rate of growth, as judged by height, could be demonstrated among these children.

In West Africa, as elsewhere, there is a tendency to restrict the child's diet during measles, accentuating nitrogen depletion. The foods that are given are mainly of 
the starchy type. Nine of the 222 children in the village study developed kwashiorkor after measles, and 4 of these died. All but one of the 9 had lost more than $10 \%$ of their weight before the onset of oedema. Kwashiorkor is occasionally seen in children who for some reason lose weight suddenly and dramatically after having previously shown satisfactory weight gains; more commonly, however, it appears after a prolonged period of failure to gain weight. This happened in the case of the four children who died. The following case history is fairly typical of these:

No. 375, F.A. $(F)$ aged 19 months. On 25 January 1960 this child was brought to the dispensary for a routine examination, and may, on that occasion, have been in contact with a child incubating measles. A typical measles rash appeared on 8 February. During the next 8 days F.A. did not appear ill, but showed a steady loss of weight. A marked desquamation of the skin was noticed, and her mother said she had lost her voice. Two weeks after the appearance of the rash, the child was brought to the clinic, oedematous and seriously ill; she died the same evening. Her weight had been almost stationary at about $19 \mathrm{lb}$. for 7 months prior to the measles, and she lost $3 \mathrm{lb} .3 \mathrm{oz} .(16.5 \%)$ of this weight during the course of the illness. Death was attributed to acute kwashiorkor, probably accompanied by an underlying bacterial infection following measles.

\section{HOSPITAL EXPERIENCE OF KWASHIORKOR FOLLOWING MEASLES AT ILESHA}

The relationship between measles and kwashiorkor is illustrated by the figures in Table 8.

It will be seen from Table 8 that the age distributions of admissions for, and deaths from, measles and kwashiorkor respectively, are very similar, except in the

Table 8. Age distribution of children with measles and kwashiorkor respectively admitted to Ilesha Hospital, July 1958-June 1961

(Figures in brackets refer to the number of deaths.)

\begin{tabular}{crrrrrr} 
& & & & & \multicolumn{3}{c}{$\begin{array}{c}\text { Children with } \\
\text { recent measles }\end{array}$} \\
Age & \multicolumn{3}{c}{$\begin{array}{c}\text { Children with } \\
\text { measles }\end{array}$} & \multicolumn{2}{c}{$\begin{array}{c}\text { Children with } \\
\text { kwashiorkor }\end{array}$} & \multicolumn{2}{c}{ kwashiorkor } \\
Under 1 & 276 & $(55)$ & 29 & $(8)$ & 12 & $(3)$ \\
$1-$ & 521 & $(156)$ & 180 & $(31)$ & 52 & $(10)$ \\
$2-$ & 217 & $(58)$ & 320 & $(34)$ & 58 & $(6)$ \\
$3-$ & 138 & $(30)$ & 163 & $(31)$ & 30 & $(9)$ \\
$4-$ & 72 & $(17)$ & 65 & $(10)$ & 11 & $(2)$ \\
$5-$ & 23 & $(3)$ & 29 & $(4)$ & 4 & $(-)$ \\
$6-$ & 33 & $(6)$ & 32 & $(6)$ & 1 & $(1)$ \\
$9-12$ & 3 & $(-)$ & 7 & $(2)$ & - & - \\
Total & 1283 & $(325)$ & 825 & $(126)$ & 168 & $(31)$
\end{tabular}

1st year, and that a considerable number of cases of kwashiorkor occurred in children who had recently had measles. Kwashiorkor developed most frequently as a sequela of measles between the 2 nd and 4 th birthdays. Since more than half 
the children with measles seen at Ilesha are under the age of 2 years (Morley, 1962), it is apparent that measles affects the child's nutrition more severely between 2 and 4 years than in the first 2 years of life, when the majority of the children are still getting some breast milk.

The importance of infection in causing protein malnutrition has recently received emphasis from Platt (1957), and from Scrimshaw, Taylor \& Gordon (1959) and Scrimshaw (1961). Investigations by Scrimshaw (1962) have shown that measles is associated with a marked negative nitrogen balance.

Gans (1961) recorded that kwashiorkor appeared after measles in a considerable number of children admitted to Lagos Hospital with measles. In Ilesha, measles was the most common of the infective illnesses of childhood which occurred, according to the histories given by the mothers, in the weeks preceding the onset of kwashiorkor.

\section{Skin changes in kwashiorkor following measles}

In children with kwashiorkor developing shortly after measles, the skin changes may be different from those seen in kwashiorkor due directly to dietary deficiency or precipitated by other illnesses. They are more widely distributed, and are frequently present on the face. Cracks may appear round the mouth. Paterson \& Lightwood (1956) give a good illustration of the appearance of a child with acute kwashiorkor after measles.

\section{Sore mouth and stomatitis}

The African mother is accustomed to prolonged breast feeding and is therefore alert to the occurrence of a sore mouth in her child. That a sore mouth may interfere with breast feeding and thus be among the causes of weight loss, was not appreciated in the earlier stages of the village study. Many mothers said that their child had a sore mouth, but only a few volunteered the information that he would not suck as a result. Later, a series of mothers whose children had been admitted to hospital with severe measles were asked whether their children had stopped sucking. Twenty-six out of 160 said that their children had gone off the breast for a period of more than 1 day. In a few cases, breast feeding had ceased for long periods, or altogether. One mother in the village group developed a breast abscess after her child had measles, and this also occurred in a number of mothers of children with measles attending the Ilesha hospital. The breast abscesses were almost certainly related to the sore mouth. The succession of events observed was: failure to suck owing to the sore mouth, engorgement of the breast, damage to the nipple from attempts to feed, infection of the damaged nipple from the infected mouth, spread of infection from the cracked nipple to the breast, and finally a breast abscess. A breast abscess naturally interferes with breast feeding and may seriously upset the child's nutrition. The importance of a sore mouth was well recognized in the past, for example, Goodhart \& Still (1921) recorded that 'the tongue and mouth become dry and ulcerated or covered with sores, and rapid emaciation takes place...' This resembles the picture often seen in West Africa, where the sore mouth caused by measles may seriously upset the nutrition of the infant. 


\section{Marasmus following measles in England before 1920}

The wasting that may occur after measles is mentioned by early writers. Creighton (1894) produced evidence that the loss of weight and emaciation associated with the disease might be an important cause of mortality. He wrote: 'We shall not correctly understand the part played by measles among the infective maladies of children unless we keep that grand character of it in mind-that its effect upon the mortality of infancy and childhood are only in part expressed by the deaths actually appearing under its name.' He drew support for this statement from 17th-century London Bills of Mortality, based on the records of women 'searchers' appointed by each parish. The records for 'consumption', 'smallpox' and 'measles' in the Bills of Mortality for the year 1674, taken from Creighton's book, are set out

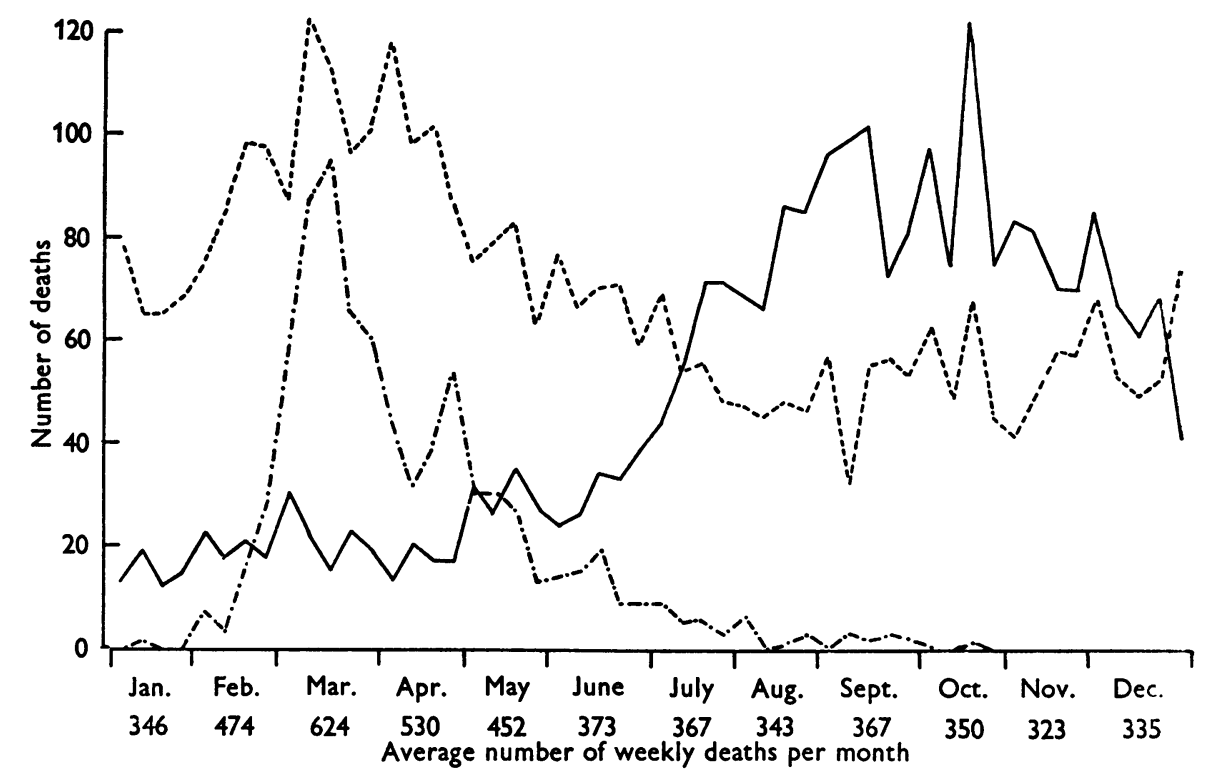

Text-fig. 1. Weekly deaths from measles, smallpox and consumption in London in 1674. -.--, Measles; — , smallpox; -..., consumption (i.e. wasting, see text).

in Text-fig. 1. Creighton's argument turns on the meaning of the word 'consumption' at the time. He quotes a Dr Fothergill, who in 1751 commented that this word had a broad meaning for the 'searchers', saying that '... if the body is emaciated, which may happen even from an acute fever, it is enough for them to place it to the account of Consumption...'

The epidemic of measles reached its peak in the week ending 17 March when 95 cases were recorded. In that week there was a total of 695 deaths, 300 above the weekly average of that season. This increase was due in part to 'consumption'. Deaths from 'teeth' and 'convulsions' also reached a peak for the year in the same season. While mortality was always higher in the spring, Creighton was confident that the exceptionally high mortality in this particular year was due to measles.

Later in the same year there was an outbreak of smallpox. Although many more 
deaths were attributed to smallpox than to measles, the total number of deaths remained lower, and, in particular, there was little or no increase in the number of deaths from 'consumption'. 'Consumption' or emaciation was doubtless due to several causes, but the fact that its incidence seems to have been much increased by the measles epidemic is significant. By 1733, age at death was also recorded in the Bills of Mortality. In that year there was a serious epidemic of measles, again associated with an increase in the number of deaths from 'consumption'. Creighton was able to show that this increase in mortality from 'consumption' was mainly among infants.

At the beginning of the present century, wasting and marasmus were still associated with measles in Northern Europe. Meunier (1898), in France, described loss of weight in the pre-eruptive stage, a sign which has been used in the differential diagnosis. The occurrence of marasmus in the later stages of the disease was also recognized.

In the village study, diarrhoea with mucus and tenesmus was among the causes of weight loss in children with measles. The time taken for children to regain their former weight after measles is shown in Table 7. If these children are separated into those with and those without diarrhoea, the mean period taken for the former to regain previous weight was $8 \cdot 06 \pm 0.31$ weeks, as compared with $4 \cdot 49 \pm 0.39$ weeks for the latter. Creighton also noticed an association between diarrhoea and weight loss, and wasting in patients suffering from measles accompanied by diarrhoea is referred to in the older literature.

It is possible that what might today be called a 'kwashiorkor-like' syndrome sometimes occurred in children after measles in earlier times in England. Creighton, in describing an epidemic in 1807, records: 'Numbers who recovered from the measles were afterwards affected with debility, cough, emaciation and oedematous swellings of the face and extremities, which proved very difficult to remove.'

\section{The rash and subsequent changes in the skin}

The unusual skin changes noticed in the Imesi and Ilesha children suggested a reason for the differences between measles in Africa and England today. In the early stages of measles in the African child, Koplik spots are commonly recognized, and the first appearance of the rash is similar to that seen in English children, when due allowance is made for the darker skin. In a proportion of the children, however, the rash became confluent. In some, it darkened to a deep red colour, and even progressed to a violet or purple hue, a change not now seen in English children. Two to four days after the appearance of the rash, desquamation began. Some degree of desquamation developed in every child in this area who had measles, the degree of desquamation being apparently related to the extent that the rash darkened in colour. In children in whom the rash acquired a purple hue, large scales of skin were likely to separate (Pl. 1).

The desquamation in the African child was more apparent for two reasons: first, the scales are white and hence show up against the dark skin, and secondly, as mentioned below, the parents believe that a child should not be washed during the course of the illness, and washing might clear away an accumulation of the 
scales. After the desquamation there was a variable and patchy depigmentation which lasted for some weeks.

A number of references to similar skin changes can be found in the older English literature. Willan (1821), who has been called 'the father of English dermatology', refers to the darkening of the rash in a child who had previously suffered from, and had presumably been weakened by, whooping cough and who then developed measles. He says: '.. the rash was succeeded by numerous livid spots, diffused over nearly the whole body, and resembling those of the Purpura...' Drinkwater (1885) described a severe measles epidemic in Sunderland during a period of industrial depression and semi-starvation. There was an $8 \%$ mortality among the children with measles under his care. In half the children the rash was unusually dark, darker than he had noticed in previous years. Moore (1892), in his Textbook of the Eruptive and Continued Fevers, refers to a 'stage of desquamation', and states that it starts at the 8th day and ends at about the 18th day after the onset of the catarrhal stage. The branny scales, he says, may not be seen as they adhere to the clothes. Another account of severe desquamation after measles is given by Edlin (1802) in a description of an epidemic in the winter of 1801-2: 'Another peculiarity in this epidemic was that the cuticle in many children did not separate after the disappearance of the eruption, and in several others that I particularly noticed, it came off in large flakes instead of branny scales; and the appearance of the rash in others assumed so striking a resemblance to the scarlet fever that, had it not been for the violent cough and other measly symptoms, many such cases occurring singly might, upon a superficial view, have been considered and treated as that disorder.'

In the 19th century excessive exfoliation of the skin following measles is likely to have been credited to scarlatina. The same possibility was considered in the earlier stages of the African studies, but was excluded on clinical grounds. The course of the disease was typically that of measles, and streptococcal disease, with its complications of nephritis and acute rheumatism, seems to be rare in this part of Africa.

Whether the type of measles seen in Nigeria, in which there is the darkening of the rash, is the same as what used to be called 'black measles', is difficult to say. Holt (1911)records that in $5 \%$ of his patients the rash was haemorrhagic; he acknowledged this as a bad, but by no means a fatal symptom. No satisfactory account of a number of cases of 'black measles' has been found, and the descriptions of individual cases vary considerably. The changes described in the rash among African children were not associated with gastro-intestinal or urinary haemorrhage, nor were they similar to thrombocytopenic purpura, which was occasionally encountered. Their appearance suggested an increased exudate of blood cells into the rash.

One final stage following desquamation was the development of multiple small boils; this was seen in 41 (18.5\%) of the children in the village study. The boils occurred most commonly on the head and trunk and usually did not appear until 2 or more weeks after the appearance of the rash. Willan (1821) records that measles could be succeeded by '...glandular swellings, and eruptions of painful 
inflamed pustules, some of them being nearly as large as boils'. In Balme's (1904) record of a measles epidemic, $12(5 \cdot 3 \%)$ of the cases suffered from subsequent impetigo. Holt (1911) stated that boils and superficial sepsis of the skin were uncommon as complications of measles, and they are rarely seen in England or the U.S.A. today.

\section{BELIEFS ABOUT MEASLES}

Reed (1957) has described some of the beliefs about measles held in West Africa. One of the most important is a conviction that measles is inevitable in young children-justified since practically every child does get measles-which makes parents indifferent towards seeking medical treatment for children with the disease. Reed noted this attitude in Ibadan, Nigeria, and it was also evident in the village study in Imesi, where it contributed to the death of three children. Within recent years some change has taken place. Thus Whitbourne (1930), writing of experience in Lagos, recorded that there were only two deaths from measles in hospitalized children in 1928 and 1929. In 1959, however, 187 children with measles were admitted to the Lagos General Hospital, 44 of whom died (Gans, 1961).

Beliefs in Europe and America have been discussed by Radbill and Hamilton (1960), who described the old remedies for measles. Apathy towards seeking medical care for children with measles was also observed in past years. It receives some mention in the Report of the Local Government Board for 1918.

Another belief mentioned by Reed is that children with measles should never be washed. This was generally held by mothers in Ilesha; some would neither wash them nor allow them water to drink. It was also prevalent in England in the past, and is still remembered by older physicians; thus Balme (1904) records, on the basis of experience at a clinic for the London poor, that mothers were averse to wetting their children when they had measles. Failure to wash leads to an accumulation of desquamating skin, and may, in the past, have increased opportunities for the physicians to observe the desquamating stage of measles.

\section{THE GENERAL CLINICAL PICTURE AND ITS VARIATIONS}

A resume of some of the main features of measles, as observed in West Africa today and reported in this paper, is given in Table 9. This is compared with the current picture in Great Britain, based largely on a Report of a Study Group of Physicians (Watson, 1956), and with the picture obtained from the works of earlier writers. As source material for what might be called the 'pre-1920' picture, the 6th edition of Holt's Diseases of Infancy and Childhood (1911) was found to be particularly useful; while Holt's account relates primarily to the U.S.A., it is in line with contemporary and earlier descriptions given by physicians in Great Britain.

\section{DISCUSSION}

The material presented in this paper suggests that measles as now seen in West Africa closely resembles the formidable disease of an earlier era in Great Britain. If this is true, then an opportunity presents itself of studying the disease as it once 
existed in Great Britain and other countries in Northern Europe and America. Such studies, which will enhance our knowledge of the disease, should be made without delay. Once an effective vaccine becomes available, it must be widely used and it will no longer be possible to observe the uncontrolled disease in communities in which its manifestations are severe.

It is proposed to discuss possible reasons for these resemblances and differences. In doing this, the virus, the environment and the host will be considered.

\section{Table 9. Features of measles in West Africa today, and in Great Britain today and before about 1920}

West Africa
(today)

17 months (Ilesha)

Common and severe

Common

Frequent

Common

Common, may be severe

Effect on child's nutrition Otitis media

Mortality
Severe

?Uncommon

$1: 20$
Great Britain (today)

4 years

Uncommon

Uncommon

Almost unknown

Unknown

Practically un-

noticed

Transient

Common

1:5000
Great Britain

(before 1920)

Under 3 years

Common and severe

Common

Frequent

Common

Common

Probably severe

Uncommon

$1: 20$ (Glasgow, 1908)

The virus. At present it is impossible to exclude altogether the possibility that the strain of measles virus which causes the disease in Nigeria and elsewhere in the tropics is more virulent than the strain occurring in England. Repeated isolation of the former and appropriate laboratory studies will be needed to reach a final conclusion on this point. However, it would seem that any virulent virus would be brought from time to time to England and other countries from the tropics, particularly in these days of 'overnight' air transport. There is no evidence that this has happened.

The environment. The child in the tropics today lives in an environment in which chances of secondary infection are high, and the same was true of the English child in the past. Today the chances of secondary infection in the English child are greatly reduced. This difference in the environment may in part account for the differences in liability to secondary infection and the mortality associated with it. Another important environmental difference, considered in this paper, is in feeding practices and state of nutrition.

The host. Catastrophic epidemics of measles have occurred in populations previously unexposed to the disease, as in Fiji and the Faroes. There is no indication of such lack of immunity, associated with sudden and lethal epidemics, in West Africa, where the disease has probably been endemic for a long time. In the measles epidemic in Accra in $\mathbf{1 8 5 2}$ described by Daniell and mentioned earlier, it was the small children who were infected and epidemics were known to be frequent. The present low mortality from measles in England can scarcely be attributed to an acquired immunity, since the decline in mortality has taken place over a period of 
50 years or so, after centuries during which the disease seems to have remained severe, with only minor variations in its severity.

Racial factors can probably be excluded. In the U.S.A. the mortality rates from measles in the negro and white population between 1921 and 1940 were similar, and declined at the same rate (Vital Statistics Rates in the U.S. 1900-1940).

A high mortality from measles seems to be related to the severity of the rash, and the subsequent desquamation. To repeat the quotation from Rhazes: 'The measles which are of a deep red and violet colour are of a bad and fatal kind'. Darkening of the rash is often seen in African children today, and seems to have been common in England in the past. Copland (1858) comments: 'The more prominent and copious the eruption, the more marked the desquamation becomes'. He also states that the red rash occurred more intensely in the ill-fed, and was associated with croup and pneumonia. It seems likely that the deep red rash and the desquamation are accompanied by equivalent changes in other epithelial surfaces of the body, which give rise to bronchopneumonia, laryngitis and diarrhoea. Gunn (1955), in his account of the morbid anatomy of measles, says: 'The essential lesions consist in a catarrhal inflammation of the respiratory and alimentary tracts. The initial inflammation of the epithelial cells is rapidly followed by fatty degeneration and by exfoliation of dead cells.' In describing the changes in the gastro-intestinal tract, he says: 'In all but the mildest attacks the whole length of the gastrointestinal tract shows an inflammatory catarrh: complete resolution is the rule, but widespread denudation of epithelium may end in mucosal atrophy.' These pathological findings are in line with experience in West Africa, where bronchopneumonia, laryngitis and chronic or relapsing diarrhoea are often encountered as complications or sequelae, tending to coincide with desquamation; they are also in line with the description or measles given by physicians in England in the past. The sequence and associations of epithelial changes in the African child may perhaps be summarized as follows:

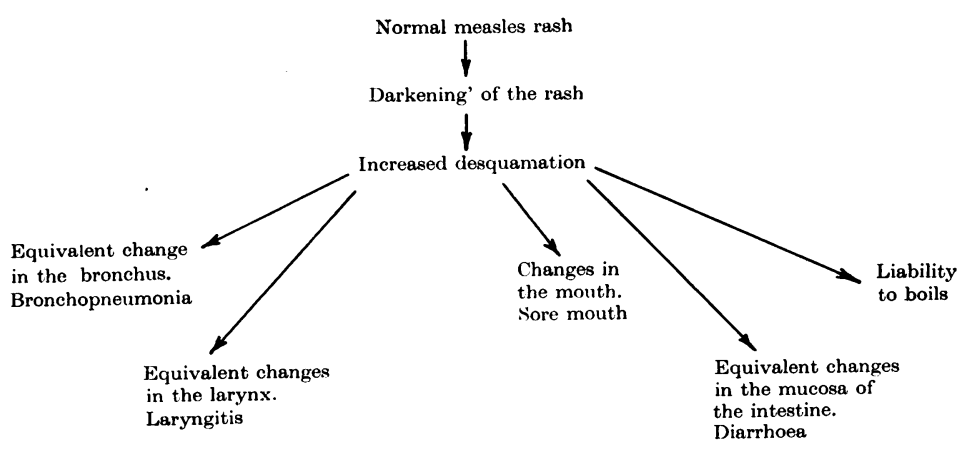

It seems that the danger of an attack of measles depends largely on the severity and extent of the epithelial lesions. The fact may provide a clue to differences in the epidemiological picture. Conceivably, a poor state of nutrition may make the epithelial surfaces more vulnerable. 


\section{SUMMARY}

1. An investigation of measles was made in Nigeria as part of a longitudinal study of 405 village children, supplemented by observations on 1,283 children admitted to a Mission Hospital with the disease.

2. Measles was found to be the most serious of the acute infectious diseases of Nigerian children. During the Imesi village study measles played a major part in the death of 15 , or $7 \%$ of the 222 children who were seen with measles. The overall case mortality in Nigeria is believed to be in the region of $5 \%$. For children admitted to hospital with the complications of measles, a mortality in excess of $20 \%$ is not infrequent. This contrasts with the present situation in Northern Europe and America, where measles is of relatively minor public health importance.

3. Bronchopneumonia was present in nearly half the children needing admission to hospital. Of those with bronchopneumonia, $28 \%$ died.

4. Diarrhoea occurred in all stages of the disease, but was most common and severe during and following the period of desquamation. Treatment by parenteral fluid to combat dehydration was required in $55 \%$ of children admitted with this complication.

5. Extensive loss of weight was associated with the disease in the majority of children. In the village study nearly one child in four lost $10 \%$ of his former weight. The mean time taken to recover former weight was $7 \cdot 2$ weeks.

6. Children frequently developed marasmus and kwashiorkor after an attack of measles.

7. Striking appearances were observed in the rash and subsequently in the skin. In some children the rash darkened in colour in the manner described by Rhazes and other early writers. Extensive desquamation often appeared after the rash. The desquamation was most severe when the rash darkened.

8. The picture of measles in this study resembles descriptions of the disease to be found in the older literature. Accounts of the incidence and severity of bronchopneumonia, laryngitis, diarrhoea and weight loss before 1920 are presented to illustrate this similarity.

9. Possible reasons for differences in the frequency and severity of measles in different places and epochs are discussed. Differences in strains of the virus and host immunity seem unlikely factors, but liability to secondary infections may be of some importance. It is concluded that the severity of the disease is related to the manifestations of the rash. A dark rash, followed by profuse desquamation, is associated with equivalent changes in the larynx, bronchus, and intestines, which are likely to be responsible for the occurrence of bronchopneumonia, laryngitis and diarrhoea. Defective nutrition is a possible cause of the 'vulnerability' of the epithelium.

The analysis of the data from Nigeria was made possible by the payment of expenses to Dr Morley by the London School of Hygiene and Tropical Medicine from July 1960 to December 1961. Subsequently the work was supported by a grant from the Medical Research Council to Prof. B. S. Platt, Head of the Department of Human Nutrition, London School of Hygiene and Tropical Medicine. 
The authors wish to thank Dr W. R. Aykroyd, Senior Lecturer, Department of Human Nutrition, for his encouragement and assistance in preparing the text, and Miss Allen and Miss Wise for secretarial help. They must also thank Professor Court of the Department of Child Health in the University of Durham for helpful criticism.

\section{REFERENCES}

Annual Report of the Registrar-General for Scotland, 1908, p. 284.

Avery, T. (1962). Private communication.

BALME, H. (1904). The signs and symptoms of measles in relation to diagnosis and prognosis, Practitioner, ii, 504.

Bouḱ, A. (1962). Private communication.

Brincker, J. A. H. (1938). A historical, epidemiological and aetiological study of measles, Proc. $R$. Soc. Med. 31, 807.

Chalmers, A. K. (1930). The Health of Glasgow, 1818-1925, p. 340. Glasgow: Bell and Bain.

Cantrelle, P. A., Etifier, J. \& Masse, N. (1960). Journées Africaines de Pédiatrie, p. 66. Paris: Centre International de l'Enfance.

Copland, J. (1858). Dictionary of Practical Medicine, vol. 2, p. 814. London: Longman, Brown, Green, Longmans and Roberts.

Creighton, C. (1894). A History of Epidemics in Britain, vol. 2, pp. 638, 651, 656. Cambridge University Press.

Danieli, W. F. (1852). On the epidemic rubeola of Accra, West Coast of Africa, Dublin Quart. J. med. Sci. 14, 25.

Drinkwater, H. (1885). Remarks upon the Epidemic of Measles prevalent in Sunderland, p. 45. Edinburgh: James Thin.

EdLIN (1802). Observations on measles, Med. phys. J. 8, 28.

Fothergint (1751). Observations of the Weather and Diseases. Quoted in Miscellaneous Works of the late R. Willan, p. 196. London: Ashby Smith. 1821.

Gannelon, C. (1892). La Rougeole à l'Hospice des Enfants Assistés. Paris: G. Steinheil.

Gans, B. (1961). Paediatric problems in Lagos, W. Afr. Med. J. 10, 33.

Gans, B., Macnamara, F. N., Morley, D. C., Thomson, S. W. \& Watt, A. (1961). Some observations on the epidemiology of measles in West Africa, W. Afr. Med. J. 10, 253.

Goodhart, J. F. \& StILl, G. F. (1921). The Diseases of Children, 11th ed., p. 223. London: Churchill.

GREgory, G. (1843). Lectures on the Eruptive Fevers, p. 111. London: Henry Renshaw.

GunN, W. (1955). Sections on measles in The British Encyclopaedia of Medical Practice (2nd ed.) 8, 407. London: Butterworth and Co.

Hout, L. E. (1911). The Diseases of Infancy and Childhood; 6th ed., pp. 932, 936. New York: D. Appleton \& Co.

McFie, J. \& Yarom, R. (1962). Child health in Luluabourg, Congo (with a note on the agedistribution of kwashiorkor). J. Trop. Paediat. 7, 123.

McGregor, I. (1962). Private communication.

Meunier, H. (1898). Sur un symptôme nouveau de la période précontagieuse de la rougeole et sur sa valeur prophylactique. Gaz. Hebd. Méd. Chir. 3, 1057.

Moore, J. W. (1892). Textbook of the Eruptive and Continued Fevers, p. 140, Dublin: Fannin and Co.

Morley, D. C. \& MacWilliam, K. M. (1961). Measles in a Nigerian Community. W. Afr. Med. J. 10, 246.

Morley, D. C. (1962). Measles in Nigeria. Amer. J. Dis. Child. 103, 230.

Murphy, E. (1962). Personal communication.

Paterson, D. \& Lightwood, R. (1956). Sick Children, 7th ed., p. 516. London: Cassell.

Platt, B. S. (1957). Protein malnutrition and infection. Amer. J. Trop. Med. 6, 773.

Radbill, S. X. \& Hamilton, G. R. (1960). Measles in fact and fancy. Bull. Hist. Med. 34, 430.

REed, F. S. (1957). Measles and folklore. W. Afr. Med. J. 6, 39.

Registrar-General's Statistical Review of England and Wales, 1960, Part I, Medical, p. 182. 
Reports of the Local Government Board, Public Health and Medical Subjects (1918). New Series, no. 115, p. 7. London: H.M.S.O.

RHAZES, (A.D. 850). A Treatise on the Smallpox and Measles. Divisio Morborum, Cap. 149, Syd. Soc., London, 1848.

SCRimshaw, N. S., TAYLOR, C. E. \& GoRdon, J. E. (1959). Interactions of nutrition and infection, Amer. J. med. Sci. 237, 367.

SCRIMSHAw, N. S. (1961). Nutrition and infection in Recent Advances in Human Nutrition, by Brock, J. F., p. 375. London: Churchill.

Scrimshaw, N. S. (1962). Private communication.

Senecal, J., Aubry, L. \& Falade, S. (1962). Infectious diseases in the child of pre-school age in Senegal. W. Afr. Med. J. 11, 93.

SyDENHAM, T. (1674). The Works of Thomas Sydenham, vol. 1, p. 185, Syd. Soc., London, 1848.

Thursfield, H. (1914). Causes of death in measles in 42nd Annual Report of the Local Government Board, 1912-13, Supplement containing the Report of the Medical Officer, appendix B, no. 2, p. 370. London: His Majesty's Stationery Office.

Trousseau, A. (1869). Lectures on Clinical Medicine, vol. 2, p. 228. New Sydenham Society.

Vital Statistics Rates in the U.S., 1900-1940 (1947). P. 284. Washington: U.S. Govt. Printing Office.

Watson, G. I. (1956). The complications of measles, Supplement to Research Newsletter, No. 11, of the College of General Practitioners.

Whitbourne, D. (1930). Notes on the infant mortality of the colony of Lagos, Nigeria. W. Afr. Med. J. 4, 3.

Willan, R. (1821). In Miscellaneous Works of the Late R. Willan, pp. 139, 288, Ashby Smith (Ed.), Cadell, Strand, London.

Winliams, D. (1906). Allbutt and Rolleston's A System of Medicine, vol. 2, part 1, pp. 390, 394. London: MacMillan and Co.

\section{DESCRIPTION OF PLATE}

Measles in an 8 months old child. The rash has blackened and areas of skin are desquamating. 


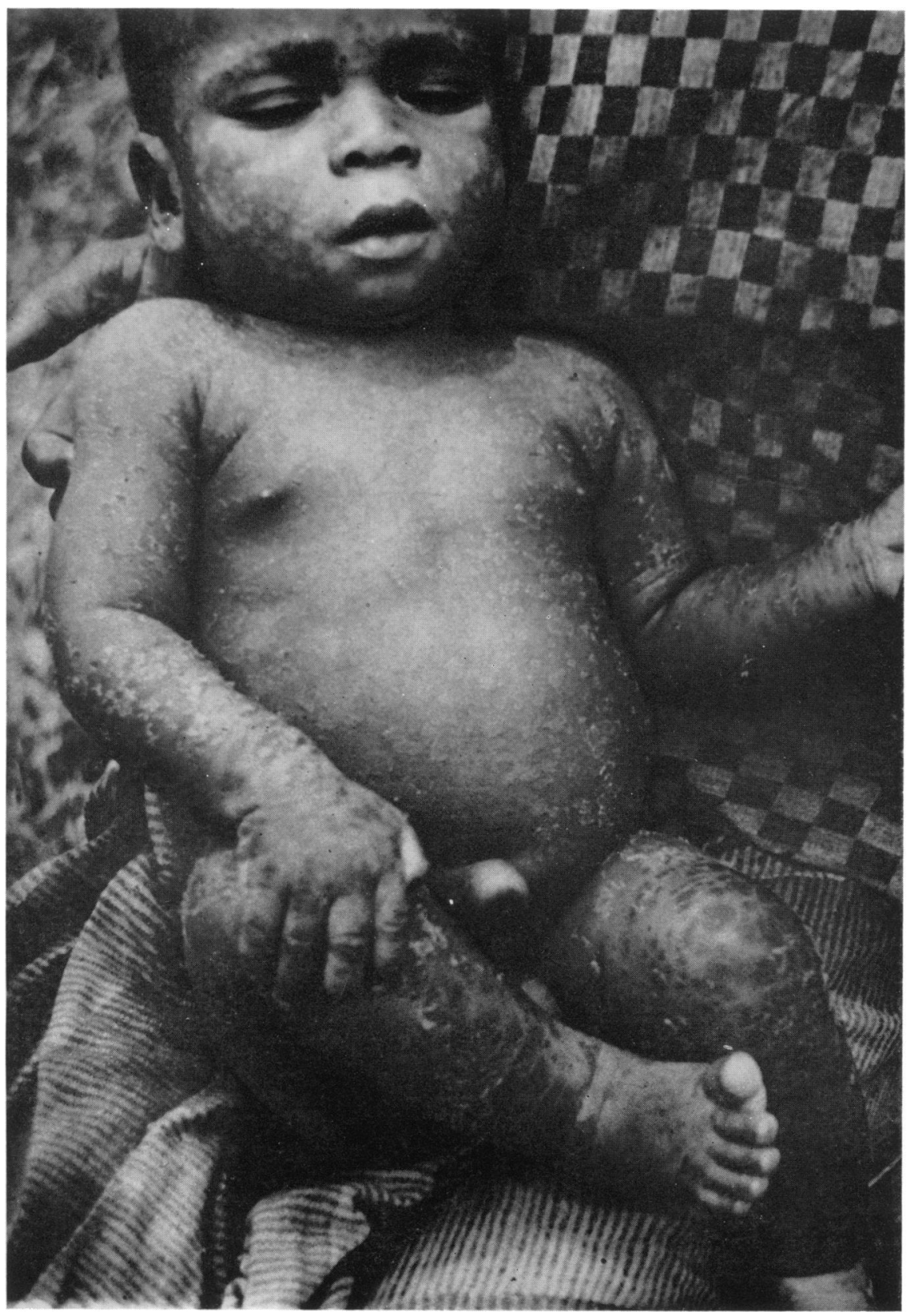

